\title{
Thunbergia laurifolia Exhibits Antifibrotic Effects in Human Hepatic Stellate Cells
}

\author{
Ratchadaporn Namsen, ${ }^{1,2}$ Noppamas Rojanasthien,, ${ }^{1}$ Seewaboon Sireeratawong, \\ Piyanuch Rojsanga, ${ }^{3}$ Wutigri Nimlamool, ${ }^{1}$ and Saranyapin Potikanond ${ }^{1}$ \\ ${ }^{1}$ Department of Pharmacology, Faculty of Medicine, Chiang Mai University, Chiang Mai, Thailand \\ ${ }^{2}$ Graduate School, Chiang Mai University, Chiang Mai, Thailand \\ ${ }^{3}$ Department of Pharmaceutical Chemistry, Faculty of Pharmacy, Mahidol University, Bangkok, Thailand \\ Correspondence should be addressed to Saranyapin Potikanond; saranyapin.p@cmu.ac.th
}

Received 22 August 2017; Accepted 13 November 2017; Published 13 December 2017

Academic Editor: Luciana Dini

Copyright (C) 2017 Ratchadaporn Namsen et al. This is an open access article distributed under the Creative Commons Attribution License, which permits unrestricted use, distribution, and reproduction in any medium, provided the original work is properly cited.

Leaves of Thunbergia laurifolia (TL) have been reported to have antioxidation, anti-inflammatory, detoxifying, and hepatoprotective effects. However, studies relating to antifibrotic activity have not been reported. Currently, there is no standard treatment for hepatic fibrosis. This study aimed to investigate the antifibrotic activity of TL in human hepatic stellate LX-2 cells. Results from cell viability and cell death assays showed that the extract at high concentrations was toxic to LX-2 cells. TL extract reversed the transformation of LX-2 cells to myofibroblast-like characteristics in response to stimulation by transforming growth factor-beta 1 . This action may be associated with the effect of TL in suppressing $\alpha$-SMA and collagen-I production observed by immunofluorescence study and western blot analysis. Additionally, TL extract significantly decreased MMP-9 activity which is consistent with the reduction of $M M P-9, M M P-2$, and TIMP-1 gene expression. The effect of TL in suppressing fibrosis may be associated with its ability to inhibit the activation of $\mathrm{p} 38 \mathrm{MAPK}$ and Erk1/2 kinases as examined by western blot analysis. Our study provides convincing evidence that TL possesses antifibrotic activity which may be through the suppression of TGF- $\beta_{1}$-mediated production of MMPs, collagen-1, and $\alpha$-SMA in hepatic stellate cells.

\section{Introduction}

A consequence of chronic liver inflammation that leads to the activation of hepatic stellate cells (HSCs) is a major cause of hepatic fibrosis $[1,2]$. One of the unique characteristics of the activated HSCs is a remarkable increase in extracellular matrix components including $\alpha$-smooth muscle actin ( $\alpha$ SMA) and collagen [3]. Hepatic fibrosis can eventually cause liver cirrhosis, which can be identified by the abnormal structure of the liver where there are fibrous scar and nodule formation of hepatocytes [4]. The number of cirrhosis related death of the world's population was reported to be over a million in 2010 [5].

HSCs are unique mesenchymal cells that account for about $5-8 \%$ of the cells in the liver [6]. Normally, HSCs are in a quiescent stage. However, liver injury or chronic inflammation results in HSC activation and differentiation into myofibroblast-like cells. These cells have high expression level of $\alpha$-SMA which has been proved to be a marker in development and progression of fibrosis [7]. $\alpha$-SMA plays a major role in fibroblast contractility in the process of wound healing and tissue fibrosis [8]. The excess of $\alpha$-SMA production can be found upon transforming growth factor-beta 1 (TGF- $\beta_{1}$ ) stimulation [9]. TGF- $\beta_{1}$ is secreted from activated HSCs and known to be an essential mediator of fibrogenesis $[10,11]$. It plays crucial roles in many biological processes including cell growth, differentiation, apoptosis, and ECM production [10-12]. Additionally, human fibroblast can be stimulated to produce more MMP-9 upon TGF- $\beta_{1}$ exposure [13]. MMPs are proteases which promote degradation of ECM components. MMP-9 or gelatinase B is known to play a major role in remodeling the ECM by digesting many molecules, 
including collagen-I [13]. Besides MMPs, tissue inhibitors of metalloproteinases (TIMPs) can also affect the outcome of fibrosis [14].

Several signal transduction pathways are responsible for contributing to liver fibrosis. Mitogen-activated protein kinases (MAPK), especially Erk1/2, are involved in proliferation and activation of HSCs as well as in regulation of many cellular functions, including cell growth and apoptosis, which can lead to a worsening of hepatic fibrosis $[15,16]$. Moreover, the activation of p38 MAP kinase is also involved in HSC activation and transformation [17].

To the best of our knowledge, there is no standard treatment for hepatic fibrosis. Therefore, searching for novel agents with antifibrotic properties is our main focus. Plants are important sources and have been used as medicines for a long time. One of those is Thunbergia laurifolia (TL) or commonly known as blue trumpet vine or laurel clock vine [18]. The major constituents of TL include phenolic compounds, flavonoids, caffeic acid, and rosmarinic acid. TL has been reported to exhibit antioxidant, anti-inflammatory, detoxifying, and hepatoprotective effects [19-23]. However, investigation relating to antifibrotic activity in human HSCs has not been documented yet. Therefore, this study aimed to investigate whether TL extract affects the level of $\alpha$-SMA, collagen-I, and MMPs in human HSCs. The possible molecular signal transduction pathways in which TL may interfere were also examined.

\section{Materials and Methods}

2.1. Preparation of Thunbergia laurifolia Extract. Thunbergia laurifolia (TL) extract was prepared by the Ouay-UnOsoth Co., Ltd. Briefly, the leaves of TL (herbarium number PYTL2013) were washed and dried at $40^{\circ} \mathrm{C}$ in a hot-air oven. Fifty kilograms of dried TL leaves was pulverized into coarse powder. TL powder was boiled in 500 liters of distilled water at $100^{\circ} \mathrm{C}$ by reflux method twice, each for $2 \mathrm{~h}$. The filtrate was evaporated and spray-dried at input temperature of $185^{\circ} \mathrm{C}$ (temperature of the heater) and then at output temperature of $86^{\circ} \mathrm{C}$ (temperature of the extract). Crude extract was dark brown and slightly bitter. Crude extract could be dissolved freely in water but slightly in 95\% ethanol. The water extract of TL was evaluated to contain total phenolic content (18.51 \pm 0.10 grams of gallic acid equivalent per 100 grams of dried extract), total flavonoid content $(3.29 \pm 0.10$ grams of quercetin equivalent per 100 grams dried extract), caffeic acid $(0.14 \pm 0.02)$, and rosmarinic acid $(0.24 \pm 0.04)$ measured by thin layer chromatography.

2.2. Cell Culture. Human hepatic stellate cell line LX-2 (Merck, Darmstadt, Germany) was used in this study. Cells were cultured in Dulbecco's modified Eagle' medium (DMEM; Gibco), supplemented with $2 \%$ fetal bovine serum (FBS), $2 \mathrm{mM}$ L-glutamine, $100 \mathrm{U} / \mathrm{mL}$ penicillin, and $100 \mu \mathrm{g} / \mathrm{mL}$ streptomycin and incubated at $37^{\circ} \mathrm{C} 5 \% \mathrm{CO}_{2}$.

2.3. Cell Viability Assay. LX-2 cells were cultured in 96-well plates at a density of $1 \times 10^{4}$ cells/well in DMEM with $2 \%$ FBS for $24 \mathrm{~h}$. Cells were treated with various concentrations of TL extract. After $24 \mathrm{~h}$, cell viability was performed using MTT (3-(4,5-dimethylthiazolyl-2)-2,5-diphenyltetrazolium bromide). The change in color intensity was measured at the absorbance of $570 \mathrm{~nm}$ by a microplate reader (BioTek Instruments, USA).

2.4. Trypan Blue Exclusion Assay. Trypan blue exclusion test was performed for evaluating the percentage of cell death. HSCs were plated in 24-well plates at a density of $3 \times 10^{4}$ cells/well and cultured in DMEM supplemented with 2\% FBS for $24 \mathrm{~h}$ at $37^{\circ} \mathrm{C} 5 \% \mathrm{CO}_{2}$. Then, $0.5 \mathrm{mg} / \mathrm{mL}$ of Thunbergia laurifolia crude extract was added to each well and cells were incubated for $0,6,9,12$, and $24 \mathrm{~h}$ at $37^{\circ} \mathrm{C}, 5 \% \mathrm{CO}_{2}$. Cells were trypsinized and diluted in $0.4 \%$ trypan blue dye at a $1: 1$ dilution and counted by using a haemocytometer.

2.5. Gelatinase Zymography. Cells were seeded in $3 \mathrm{~cm}$ dishes at a density of $0.3 \times 10^{6}$ cells per well and cultured for $24 \mathrm{~h}$. After TL treatment for $24 \mathrm{~h}$, culture supernatants were collected and mixed with nonreducing sample buffer, and samples were separated by SDS-PAGE in a cold running condition. Following electrophoresis, the gels were washed twice in $2.5 \%$ Triton X-100 for $30 \mathrm{~min}$ at RT. The gels were then incubated with substrate buffer $(50 \mathrm{mM}$, Tris-HCL, and $10 \mathrm{mM} \mathrm{CaCl}_{2} \mathrm{pH} \mathrm{8)}$ overnight. The gels were stained with $0.5 \%$ Coomassie Blue R250 in 50\% methanol and 10\% glacial acetic acid for $30 \mathrm{~min}$, and then destaining was performed. The intensity of each band was evaluated using ImageJ software.

2.6. Quantitative RT-PCR. LX-2 cells were seeded at a density of $0.3 \times 10^{6}$ cells/well in $3 \mathrm{~cm}$ dishes. Cells were stimulated with or without TGF-beta $1(1 \mathrm{ng} / \mathrm{mL})$ for $24 \mathrm{~h}$ before further incubated with different concentrations of TL extract for $24 \mathrm{~h}$ at $37^{\circ} \mathrm{C} 5 \% \mathrm{CO}_{2}$. Total RNA was extracted by a total RNA extraction kit (Vivantis, USA) according to the manufacturer's protocol. cDNA was prepared using reverse transcriptase master mix (Toyobo, Japan) following the ReverTra Ace ${ }^{\circledR}$ qPCR RT master mix protocol. Realtime PCR reaction was performed $\left(2 \mathrm{~min}\right.$ at $50^{\circ} \mathrm{C}$ and then $2 \mathrm{~min}$ at $95^{\circ} \mathrm{C}$ for activation, $15 \mathrm{~s}$ at $95^{\circ} \mathrm{C}, 15 \mathrm{~s}$ at $58^{\circ} \mathrm{C}$, and $1 \mathrm{~min}$ at $72^{\circ} \mathrm{C}$ for 40 cycles of amplification) using $\mathrm{SYBR}^{\circledR}$ Green PCR Master Mix (Applied Biosystems, USA). A set of primers included TIMP-1: L: CTTCTGCAATTCCGACCTCGT, R: CCCTAAGGCTTGGAACCCTTT; MMP-2: L: ACATCAAGGGCATTCAGGAG, R: GCCTCCGTATACCGCATCAAT; MMP-9: L: CCCGGAGTGAGTTGAACCA, R: GGATTTACATGGCACTGCCA; and GAPDH: L: ATGGGGAAGGTGAAGGTCG, R: GGGGTCATTGATGGCAACAATA.

2.7. Western Blot. LX-2 cell lysates were prepared by adding $1 \mathrm{x}$ reducing Laemmli buffer into the sample dishes. Samples were collected, heated at $95^{\circ} \mathrm{C}$ for $5 \mathrm{~min}$, separated by SDSPAGE, and electroblotted onto PVDF membrane (GE Healthcare Life Sciences, Germany). Membranes were blocked with $5 \%$ skim milk in TBS-T (0.02 M Tris- $\mathrm{HCl}, \mathrm{pH} 7.6,0.0137 \mathrm{M}$ $\mathrm{NaCl}$, and $0.1 \%$ Tween 20) at RT for $1 \mathrm{~h}$. Membranes were then incubated with an appropriate antibody (Cell Signaling 


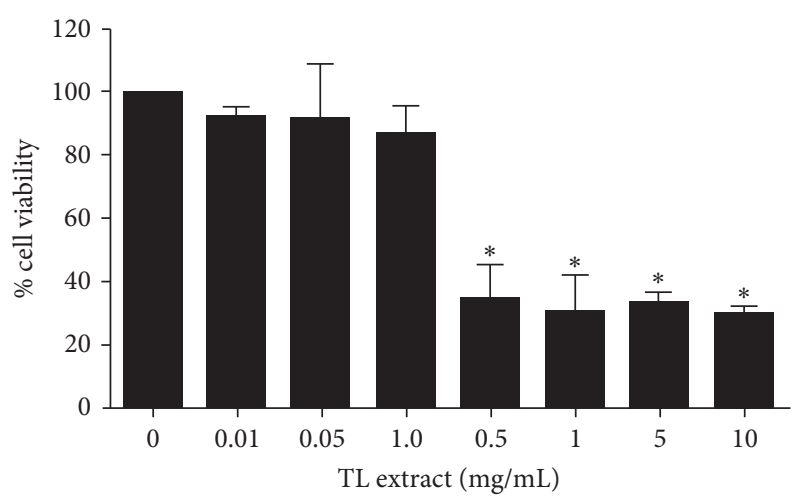

(a)

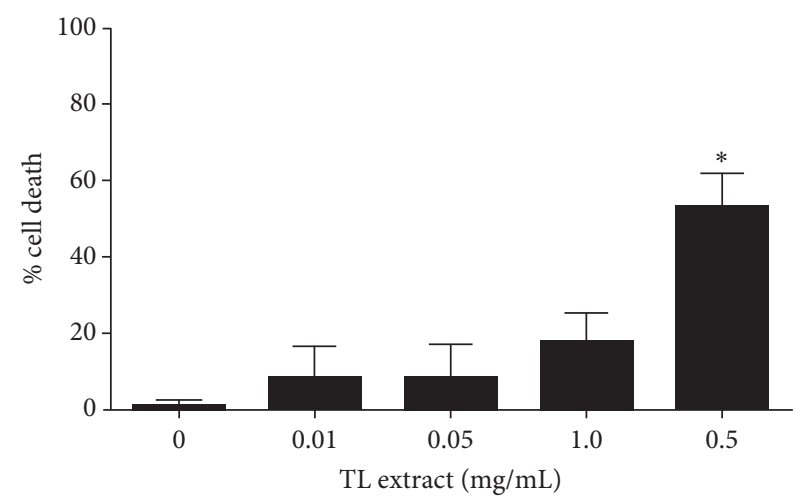

(b)

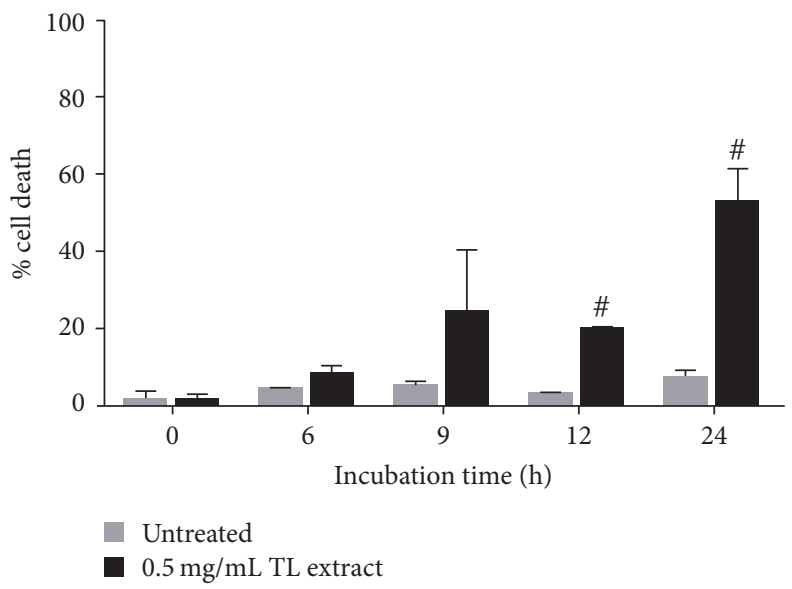

(c)

FIGURE 1: Effects of TL extract on cell viability and cell death. Bar chart indicates the percent of cell viability of LX-2 cells treated with TL extract $(0-10 \mathrm{mg} / \mathrm{mL})$ for $24 \mathrm{~h}$ and cell viability was measured by MTT assay (a). Cell death was measured by trypan blue exclusion test of cells treated with different concentrations of TL extract (b) and at different time points of cells treated with TL at $0.5 \mathrm{mg} / \mathrm{mL}$ (c). ${ }^{*} P<0.05$ indicates statistical significance from untreated group. ${ }^{*} P<0.05$ indicates statistical significance from time point 0 of $0.5 \mathrm{mg} / \mathrm{mL}$ TL extract.

Technology, USA) at $4^{\circ} \mathrm{C}$ overnight. Primary antibodies used included a $1: 1,000$ dilution of an anti- $\alpha$-SMA antibody, or an anti-collagen-I antibody, or an anti-Akt (Ser 473) (D9E) antibody, a phosphospecific anti-Erk1/2 (Thr 202/Tyr 204) antibody, or a phosphospecific anti-p38 MAPK, and a 1:10,000 dilution of an anti-beta-actin antibody. After three washes with TBS-T, membranes were incubated with a 1:5000 dilution of an appropriate horseradish peroxidaseconjugated secondary antibody (KPL, USA) for $2 \mathrm{~h}$, at RT. Immune complexes were detected using enhanced chemiluminescence reagent. The intensity of immunoreactive bands was analyzed and quantified using ImageJ software.

\section{Results}

3.1. The Effects of TL on LX-2 Cell Viability and Cell Death. Since we focused mainly on antifibrotic activity of TL, we first evaluated its cytotoxicity to human hepatic stellate cell line (LX-2) by MTT assay. We found that cells treated with $\mathrm{TL}$ extract at a range of concentrations $(0.01,0.05,0.1,0.5$, 1,5 , and $10 \mathrm{mg} / \mathrm{mL}$ ) for $24 \mathrm{~h}$ showed significant reduction in cell viability, especially at $0.5,1,5$, and $10 \mathrm{mg} / \mathrm{mL}$ as shown in Figure 1(a). The IC50 of TL extract was $0.2 \mathrm{mg} / \mathrm{mL}$. Since results from cell viability test showed that TL extract at high concentrations exhibited a drastic decrease in cell viability, we speculated that the reduction of cell viability was due to induction of cell death. Therefore, we performed trypan blue exclusion assay and found that TL extract induced LX-2 cell death in a concentration-dependent manner. The percent cell death was $8.12 \pm 8.35 \%, 8.49 \pm 8.60 \%, 17.88 \pm 8.49 \%$, and 53.16 $\pm 8.63 \%$ for cells treated with TL extract at $0.01,0.05,0.1$, and $0.5 \mathrm{mg} / \mathrm{mL}$, respectively (Figure $1(\mathrm{~b})$ ). We next examined the cytotoxic effect of TL at different time points and discovered that TL extract tended to induce cell death at early time point $(6 \mathrm{~h})$ and the percentage of cell death gradually increased over time (Figure $1(\mathrm{c})$ ). Data showed that TL extract induced approximately $53 \%$ of cell death after $24 \mathrm{~h}$ of incubation, whereas the control (untreated) group showed no observable cell death at all time points. Based on our observation that TL extract at concentrations between 0.01 and $0.1 \mathrm{mg} / \mathrm{mL}$ did not have any cytotoxic effect to LX-2 cells, we therefore used these nontoxic concentrations to further explore antifibrotic activity of TL.

3.2. The Effects of TL on Reversing TGF- $\beta_{1}$-Induced Cell Transformation. A known cytokine, TGF- $\beta_{1}$, is normally 


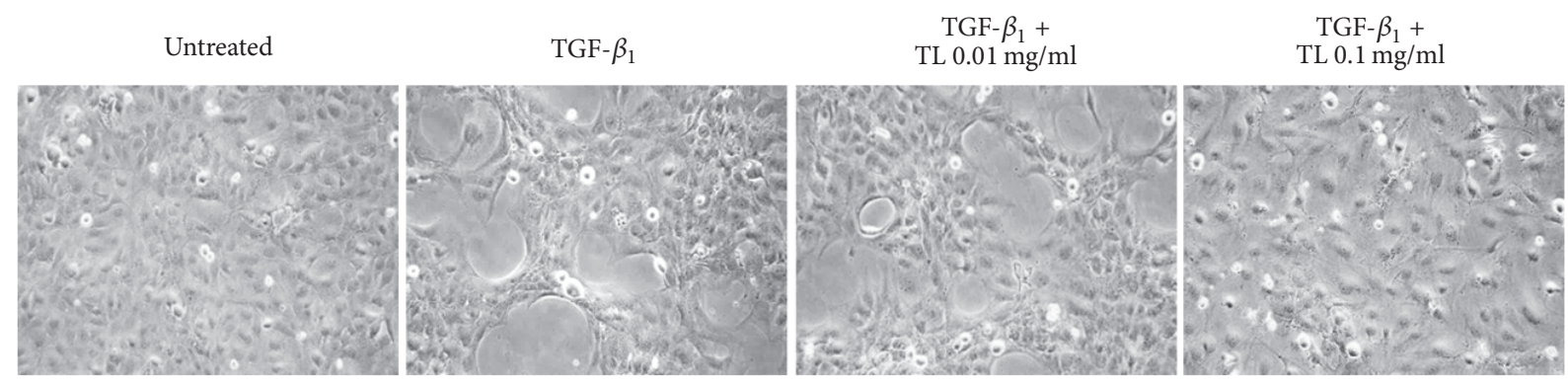

(a)

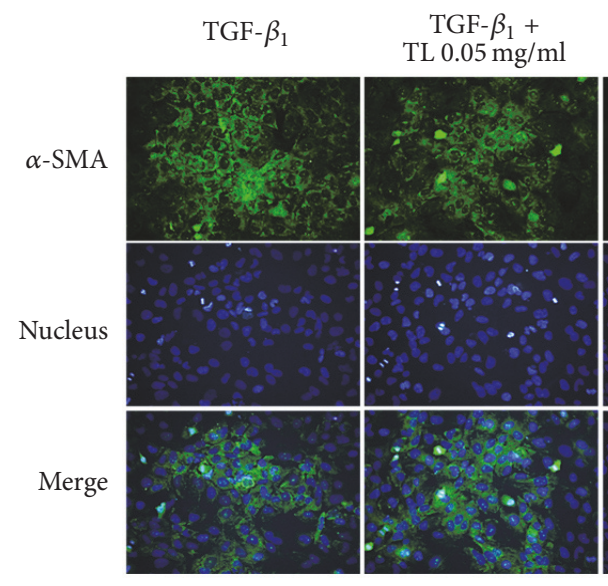

(b)

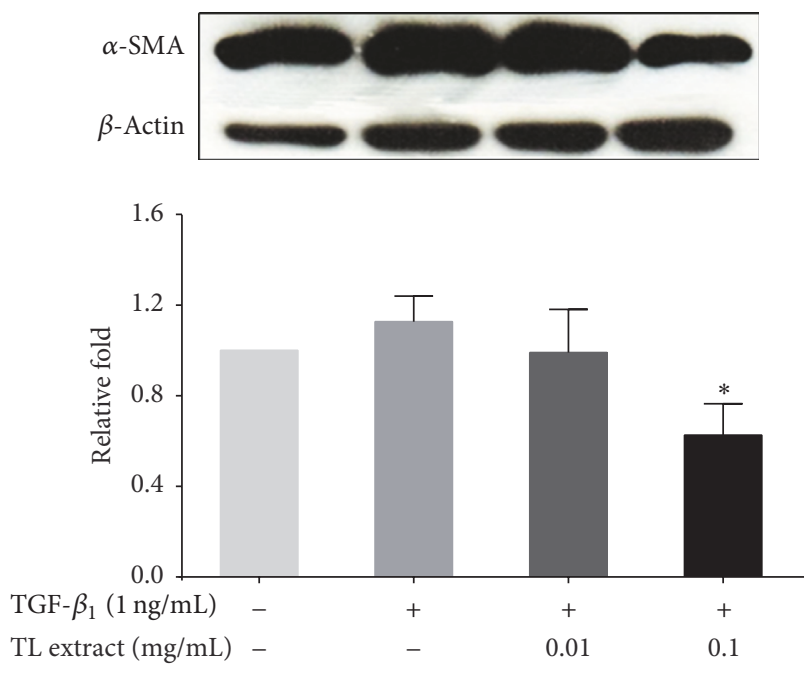

(c)

FIGURE 2: Effects of TL extract on reversing the morphology of TGF- $\beta_{1}$-treated cells. Morphology of LX-2 cells observed by a phase-contrast microscope (a). Immunofluorescence study of $\alpha$-SMA (b), and western blot analysis of $\alpha$-SMA (c) in LX-2 cells stimulated with or without TGF- $\beta_{1}$ and treated with TL extract. Actin was used as a loading control. ${ }^{*} P<0.05$ indicates statistical significance from TGF- $\beta_{1}$-treated group.

produced during liver injury. This cytokine can stimulate hepatic stellate cells to increase the production of extracellular matrix (ECM) [24] and $\alpha$-smooth muscle actin ( $\alpha$-SMA) $[9,25]$. Upon TGF- $\beta_{1}$ stimulation, LX- 2 cells can be activated and transformed into myofibroblasts and lose their original characteristics [26]. Figure 2(a) shows that LX-2 cells without any treatment exhibited normal cell morphology showing star-shaped stellate cells with discrete cell-to-cell contact. In contrast, LX-2 cells stimulated with TGF- $\beta_{1}$ induced cell transformation to myofibroblast-like morphology. These cells exhibited cell stretching and clumping with many obvious cell-free areas. Interestingly, TGF- $\beta_{1}$-stimulated cells treated with TL extract $(0.01 \mathrm{mg} / \mathrm{mL}$ and $0.1 \mathrm{mg} / \mathrm{mL})$ reversed transformation of LX-2 cell to myofibroblast in a concentrationdependent manner.

3.3. The Effect of TL on Suppressing $\alpha$-SMA and Collagen Production. Since TGF- $\beta_{1}$-induced transformation has been reported to be associated with an increase in $\alpha$-SMA content $[9,27,28]$, we therefore performed immunofluorescence study to evaluate $\alpha$-SMA production. We observed that treating cells with TGF- $\beta_{1}$ potently induced $\alpha$-SMA protein production in the cytoplasm. Interestingly, TL extract at
0.05 and $0.1 \mathrm{mg} / \mathrm{mL}$ could drastically reduce $\alpha$-SMA production (Figure 2(b)). The blue signal from Hoechst 33342 staining for nuclear detection showed approximately equal number of cells on glass cover slips, and the nuclear signal intensity was similar in all groups. Consistent with the results from immunofluorescence study, western blot analysis detecting immunoreactive bands of $\alpha$-SMA revealed that TL extract could significantly reduce the production of $\alpha$ SMA upon TGF- $\beta_{1}$ stimulation (Figure 2(c)). The maximal reduction was observed to be approximately $0.63 \pm 0.14$ fold compared to that of the TGF- $\beta_{1}$-stimulated group. We also determined whether the expression of important molecules involved in modulating extracellular matrix is suppressed by the effect of TL extract. The results from immunofluorescence study for collagen-I were similar to those observed in $\alpha$-SMA staining. When the concentration of TL extract was increased, collagen-I protein production was significantly reduced (Figure 3(a)). Results from western blot confirmed the observation from immunofluorescence where a concentration-dependent reduction of collagen-I was observed. TGF- $\beta_{1}$-stimulated cells treated with 0.01 and $0.1 \mathrm{mg} / \mathrm{mL}$ of TL extract showed the reduction of collagen-I production $(0.78 \pm 0.36$-fold and $0.5 \pm 0.1$-fold $)$, respectively, 


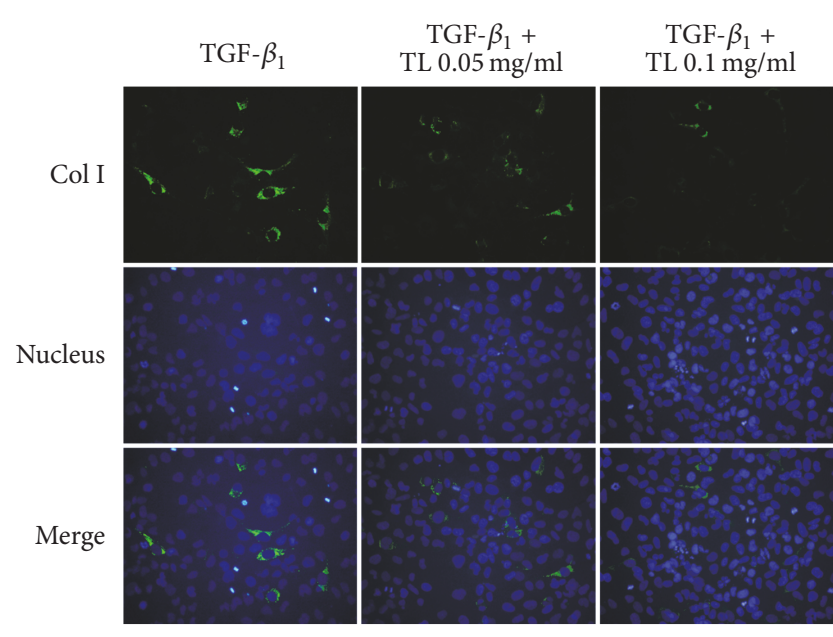

(a)
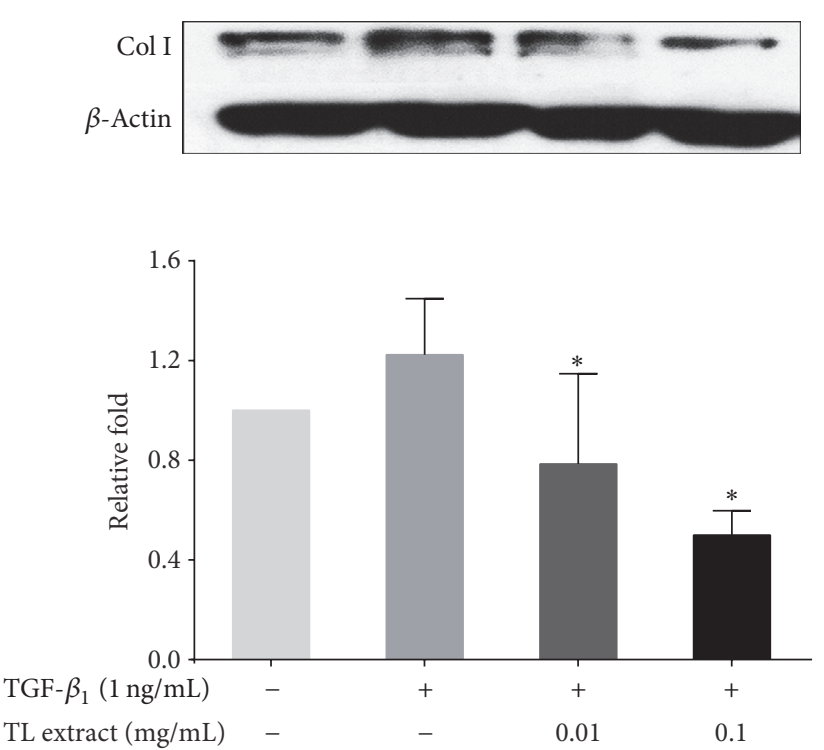

(b)

FiguRE 3: Effects of TL extract on collagen-I expression. Immunofluorescence study of collagen-I (a) and western blot analysis of collagen-I (b) in LX-2 cells stimulated with or without TGF- $\beta 1$ and treated with TL extract. Actin was used as a loading control. ${ }^{*} P<0.05$ indicates statistical significance from TGF- $\beta_{1}$-treated group.

compared to the collagen-I level in TGF- $\beta_{1}$-stimulated cells without TL extract exposure which was $1.22 \pm 0.22$-fold.

3.4. The Effect of TL on Inhibiting MMP-9 Activity. Based on the fact that MMP-9 (gelatinase B) is one of fibrotic markers reported to be upregulated in liver fibrosis and is a major MMP in basement membrane-like ECM remodeling [29], we therefore determined whether TL extract can suppress MMP-9 activity. Data from zymographic analysis showed that the extract at noncytotoxic concentrations $(0.01,0.05$, and $0.1 \mathrm{mg} / \mathrm{mL}$ ) could effectively reduce MMP-9 activity (Figure 4(a)). The percentage of MMP-9 activity of cells treated with TL extract at $0.01,0.05$, and $0.1 \mathrm{mg} / \mathrm{mL}$ was reduced to $78.89 \pm 8.04 \%, 55.77 \pm 4.47 \%$, and $37.94 \pm 7.24 \%$, respectively. Moreover, even though cells were stimulated with TGF- $\beta_{1}$, TL extract was still able to suppress MMP-9 activity in a concentration-dependent manner. The percent reduction of MMP-9 activity was $85.76 \pm 25.79 \%, 47.46 \pm$ $1.93 \%$, and $29.06 \pm 3.24 \%$ for cells treated with TL extract at $0.01,0.05$, and $0.1 \mathrm{mg} / \mathrm{mL}$, respectively. We further explored the effect of TL on suppressing MMP-9 gene expression along with other relevant molecules including MMP-2 and TIMP-1. Data from quantitative PCR confirmed that the extract could be able to suppress these genes in a concentration-dependent manner (Figure 4(b)).

3.5. The Effects of TL on Intracellular Signaling Pathways. Several signaling molecules are involved in fibrogenic process in response to TGF- $\beta_{1}$ stimulation. These molecules include p38 MAPK and Erk1/2 proteins $[15,17]$. Thus we defined the mechanism of action whether TL suppresses fibrosis via inhibiting the activation of these molecules. We found that TGF- $\beta_{1}$ alone increased the activation of $\mathrm{p} 38$ MAPK protein. On the other hand, TGF- $\beta_{1}$-stimulated cells treated with TL extract showed a significant decrease in phosphorylation of p38 MAPK in a concentration-dependent manner (Figure 5(a)). Similarly, phosphorylation of Erk1/2 was reduced when the concentration of TL extract was increased (Figure 5(b)). However, we observed no change in the phosphorylation status of Akt kinase which is a crucial molecular marker for survival signaling that plays a crucial role in the balance of HSC activation and apoptosis (Figure 5(c)).

\section{Discussion}

Hepatic fibrosis is a wound-healing response to chronic liver injury characterized by progressive inflammation and deposition of extracellular matrix (ECM) components [30]. During the development of fibrosis, hepatic stellate cells (HSCs) or myofibroblast-like cells are activated to synthesize excessive collagen and $\alpha$-SMA leading to liver cirrhosis [4, 31]. Currently, there is no standard treatment for liver fibrosis. Therefore, agents that can be able to inhibit the production of $\alpha$-SMA and collagen in activated HSCs would be excellent candidates for developing a potential treatment for liver fibrosis.

Our study aimed to investigate the antifibrotic activity of Thunbergia laurifolia. We focused mainly on the plant's ability to suppress $\alpha$-SMA and collagen production in LX-2 cells which are an activated human hepatic stellate cell line [26]. In order to examine the antifibrotic activity of TL, we first assayed for its cytotoxicity to LX-2 cells. Based on the data from cell viability test showing that the low range of 

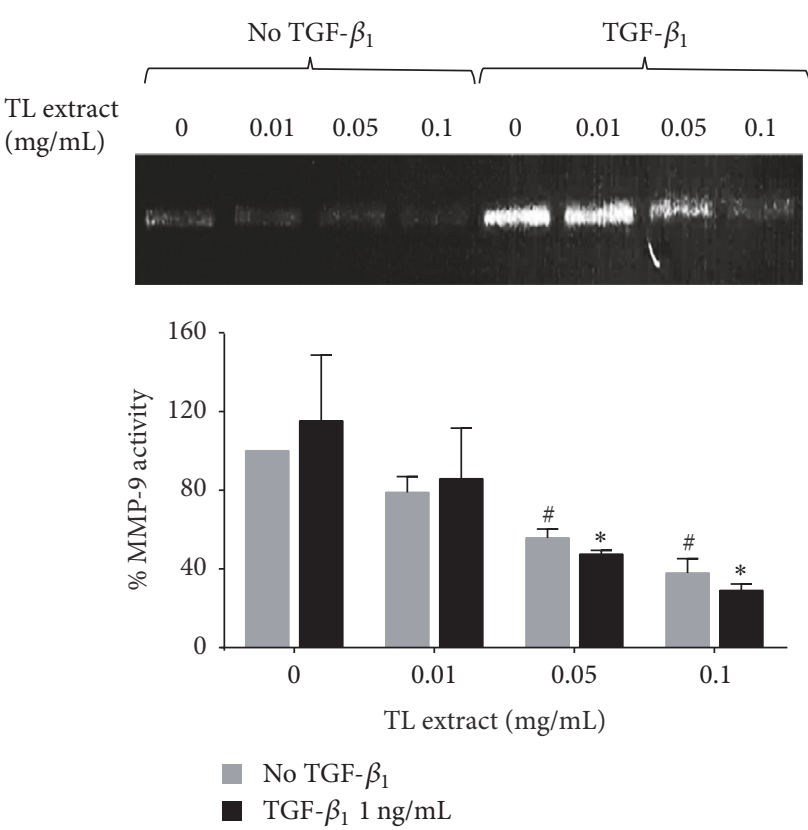

(a)
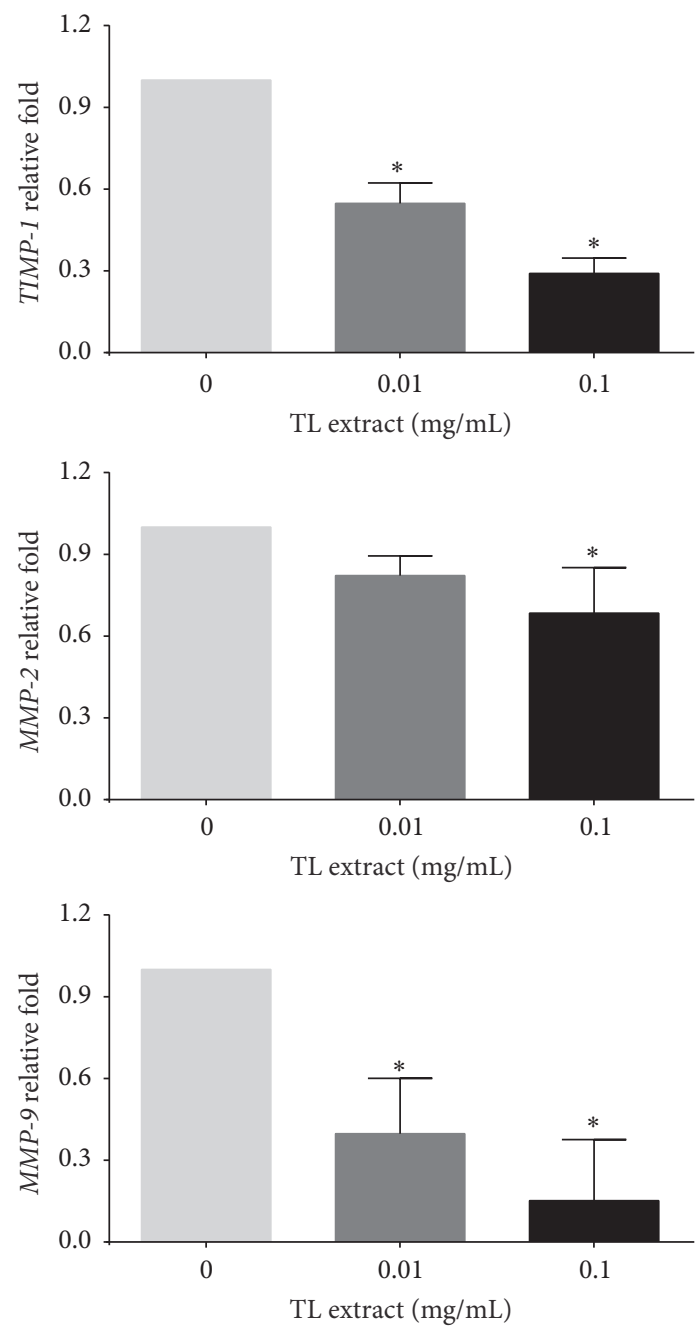

(b)

Figure 4: Effects of TL extract on MMP-9 activity and mRNA expression of TIMP-1, MMP-2, and MMP-9 genes. MMP-9 activity of LX-2 cells were investigated by gelatin zymography. Bar graphs in zymogram represent the percentage of MMP-9 activity (a). ${ }^{\#} P<0.05$ indicates statistical significance from no TGF- $\beta_{1}$ group. ${ }^{*} P<0.05$ indicates statistical significance from TGF- $\beta_{1}$-treated group. Gene expression of TIMP-1, MMP-2, and MMP-9 was measured by quantitative RT-PCR (b). GAPDH was used as an internal control. ${ }^{*} P<0.05$ indicates statistical significance from TGF- $\beta_{1}$-treated group.

concentrations did not show any toxicity to the cell, therefore, in this study we chose the nontoxic concentrations of TL $(0.01-0.1 \mathrm{mg} / \mathrm{mL})$ to evaluate the antifibrotic activity of TL.

It has been well known that TGF- $\beta_{1}$ which is a key regulator of extracellular matrix (ECM) assembly and remodeling is involved in hepatic fibrosis $[10,11]$. In general, TGF- $\beta_{1}$ induces the expression of ECM proteins in mesenchymal cells and stimulates the production of protease inhibitors that prevent enzymatic breakdown of the ECM. Based on this reason, we used TGF- $\beta_{1}$ to stimulate LX-2 cells for enhancing the production of $\alpha$-SMA protein, collagen-I, and metalloproteinase-9 (MMP-9) and explored the inhibitory effects of TL on the level of $\alpha$-SMA protein, collagen-I, and MMP-9 in TGF- $\beta_{1}$-stimulated LX-2 cells. The results from phase-contrast microscopy showed that TL extract at $0.1 \mathrm{mg} / \mathrm{mL}$ could reverse the morphology of TGF- $\beta_{1}$ stimulated LX-2 cells from star-like morphology to normal characteristics when compared to the untreated cells. The results suggest that there must be some changes in the level of specific cytoskeletal proteins in TL-treated cells. Surprisingly, TL extract significantly reduced the production of $\alpha$-SMA. For $\alpha$-SMA, when HSCs are activated, intense cytoplasmic $\alpha$-SMA level is increased. This protein is an actin isoform and a specific marker for muscle cell differentiation [32]. The level of $\alpha$-SMA production can be used to identify activated HSCs which exhibit a myofibroblastic phenotype [33-35]. Therefore, our finding that TL could potently suppress $\alpha$ SMA production suggests the role of TL in inhibiting cell differentiation and transformation in response to TGF- $\beta_{1}$ stimulation. Besides, TL also suppressed the production of 

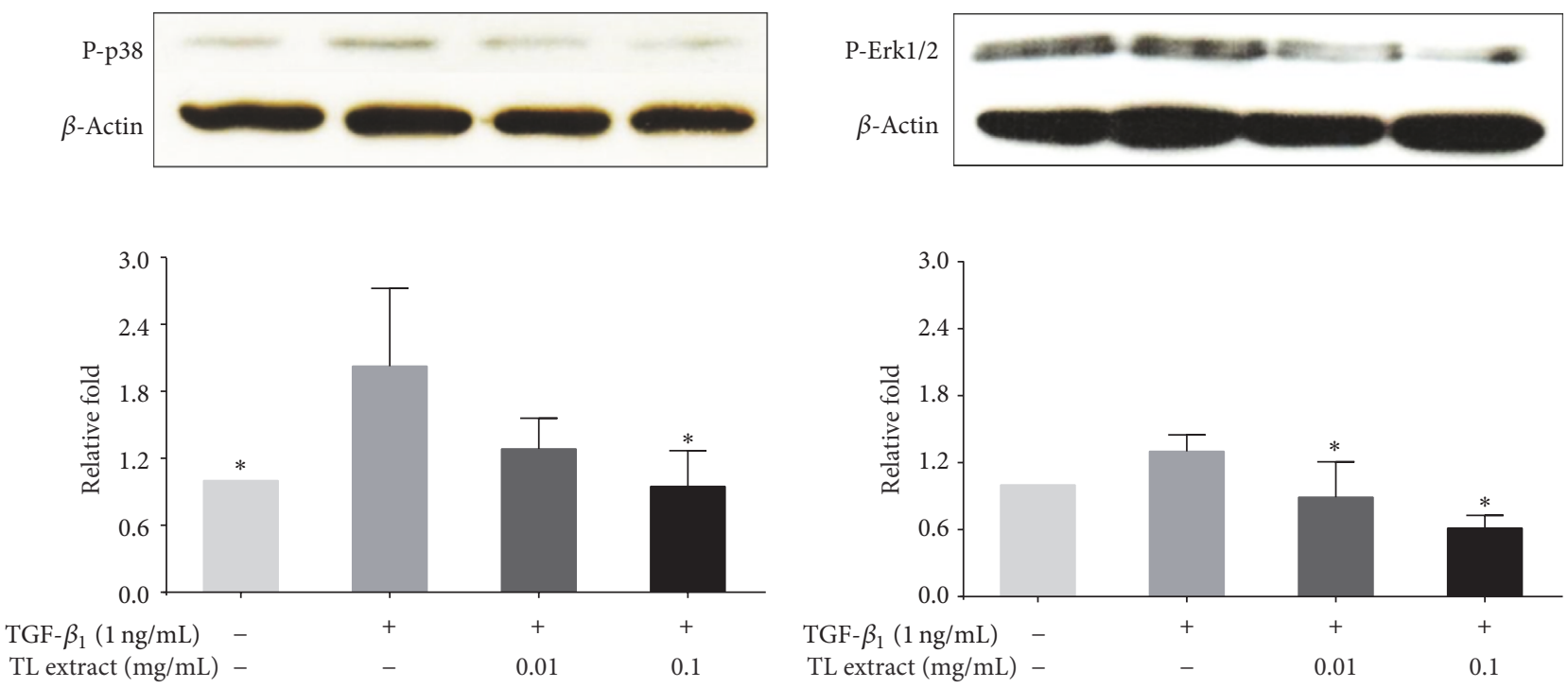

(a)

(b)
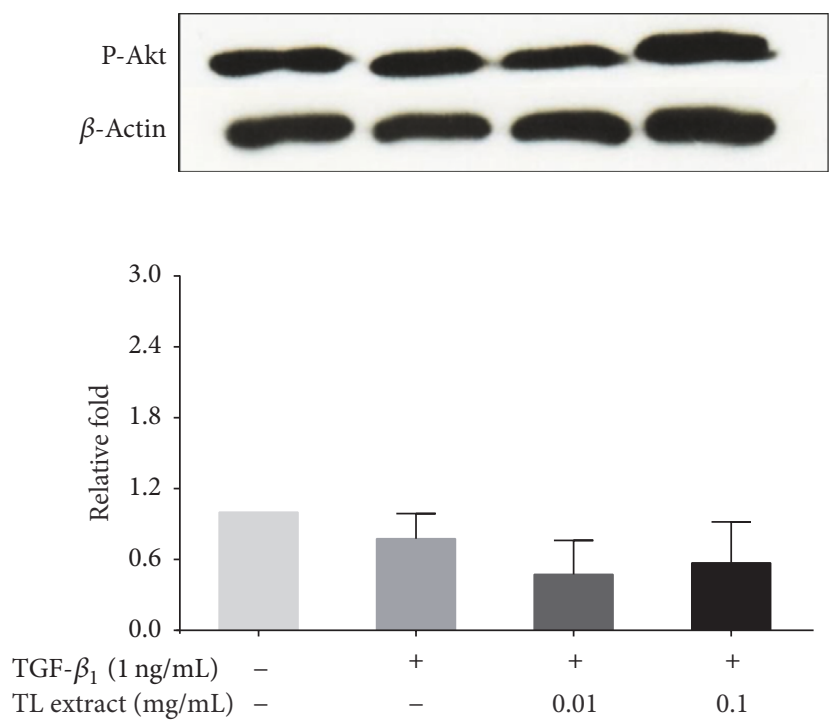

(c)

Figure 5: Effects of TL extract on phosphorylation of p38, Erk1/2, and Akt in LX-2 cells induced by TGF- $\beta_{1}$ and treated with TL extract. Phosphorylation of p38 MAPK, Erk1/2, and Akt is shown in (a), (b), and (c), respectively. The bar graphs represent the relative fold of phosphorylated p38, Erk1/2, and Akt kinases. ${ }^{*} P<0.05$ indicates statistical significance from TGF- $\beta_{1}$-treated group.

collagen-I in TGF- $\beta_{1}$-stimulated cells in a concentrationdependent manner. The data suggest that TL interferes with TGF- $\beta_{1}$-signaling that normally activates HSCs to undergo morphological changes to a myofibroblastic phenotype.

Collagen generation and degradation mediated by matrix metalloproteinases and tissue inhibitors of metalloproteinases can affect the outcome of fibrosis [36]. Therefore, the balance between MMPs and TIMPs is important in collagen degradation. When we performed the experiment for measuring the activity of MMP-9 by gelatin zymography, we found that TL extract inhibited the production of MMP-9 in LX-2 cells. Additionally, even though LX-2 cells were stimulated with TGF- $\beta_{1}$, TL extract was still able to significantly suppress MMP-9 activity in a concentrationdependent manner. When we performed quantitative RTPCR for MMP-2, MMP-9, and TIMP-1 genes, significant decreases in the expression level of these genes were observed. It has been reported that the expression of MMPs and TIMPs is increased in liver fibrosis and contributes to both the progression and regression of fibrosis [2]. In particular, there are studies showing the correlation between the level of TIMP-1 in the serum and fibrosis activity [37], and this specific protein is now a component of noninvasive serum markers of fibrosis [38]. In short, our discovery that TL extract significantly reduced the expression of MMPs and TIMP-1 provides accumulated evidence. These data may be 
beneficial for further investigation to verify whether TL possesses a potent effect slowing the progression of hepatic fibrosis.

Several molecular signal transduction pathways are responsible for the pathogenesis of hepatic fibrosis. One of those signaling pathways is mitogen-activated protein kinase (MAPK) involved in proliferation, activation of HSCs, and regulation of many cellular functions, including apoptosis which can lead to a worsening of hepatic fibrosis $[15,17]$. TGF$\beta_{1}$ stimulates the activation of p38 MAPK and Erk1/2 which further activate specific transcription factors for specific responsive elements of profibrotic genes including collagen-I. We, therefore, tried to define the possible molecular mechanism of action to explain how TL works in modulating TGF$\beta_{1}$-induced fibrosis. The results showed that TL extract could suppress phosphorylation of p38 MAPK and Erk1/2 which are involved in proliferation and activation of HSCs. The observation indicates that the activation of these two kinases is potently suppressed by the action of TL. We observed that TL extract did not suppress phosphorylation of Akt kinase. This indicates that Akt is still active in maintaining the balance of cell survival. This observation was consistent with the results from MTT assay showing that TL extract at the selected concentrations for examining antifibrotic activity did not interfere with the viability of LX-2 cells and, thus, $\mathrm{TL}$ extract does not have any effect on suppressing cell survival.

In conclusion, the present study demonstrated that TL possesses antifibrotic properties. The extract from this plant could reduce the production of fibrotic markers which include $\alpha$-SMA, collagen-I, and MMPs. The possible mechanism of action of TL may be through its interference in TGF$\beta_{1}$-dependent signal transduction pathways: p38 MAPK and Erk1/2. Our finding provides for the first time that TL has potent ability to suppress the activation of hepatic stellate cells and suggests that TL could be a potential therapeutic agent for hepatic fibrosis.

\section{Disclosure}

The funders had no role in the project design, data collection, interpretation, or decision to publish.

\section{Conflicts of Interest}

There are no conflicts of interest. None of the authors have a direct financial relation with any of the commercial identities mentioned in the paper.

\section{Acknowledgments}

This work was supported by CMB Funding, Faculty of Medicine, Chiang Mai University, and the Center for Innovation in Chemistry (PERCH-CIC), Commission on Higher Education, Ministry of Education (at Faculty of Science, Mahidol University, Thailand). The authors also are thankful for the supports from Research Center of Pharmaceutical Nanotechnology, Chiang Mai University.

\section{References}

[1] R. Bataller and D. A. Brenner, "Hepatic stellate cells as a target for the treatment of liver fibrosis," Seminars in Liver Disease, vol. 21, no. 3, pp. 437-451, 2001.

[2] J. P. Iredale, "Hepatic stellate cell behavior during resolution of liver injury," Seminars in Liver Disease, vol. 21, no. 3, pp. 427436, 2001.

[3] G. Carpino, A. Franchitto, S. Morini, S. G. Corradini, M. Merli, and E. Gaudio, "Activated hepatic stellate cells in liver cirrhosis. A morphologic and morphometrical study," Italian Journal of Anatomy and Embryology, vol. 109, no. 4, pp. 225-238, 2004.

[4] R. Bataller and D. A. Brenner, "Liver fibrosis," The Journal of Clinical Investigation, vol. 115, no. 2, pp. 209-218, 2005.

[5] A. A. Mokdad, A. D. Lopez, S. Shahraz, R. Lozano, A. H. Mokdad, J. Stanaway et al., "Liver cirrhosis mortality in 187 countries between 1980 and 2010: a systematic analysis," BMC Medicine, vol. 12, article 145, 2014.

[6] C. Yin, K. J. Evason, K. Asahina, and D. Y. R. Stainier, "Hepatic stellate cells in liver development, regeneration, and cancer," The Journal of Clinical Investigation, vol. 123, no. 5, pp. 1902-1910, 2013.

[7] N. Akpolat, S. Yahsi, A. Godekmerdan, M. Yalniz, and K. Demirbag, "The value of $\alpha$-SMA in the evaluation of hepatic fibrosis severity in hepatitis B infection and cirrhosis development: a histopathological and immunohistochemical study," Histopathology, vol. 47, no. 3, pp. 276-280, 2005.

[8] B. Hinz, G. Celetta, J. J. Tomasek, G. Gabbiani, and C. Chaponnier, "Alpha-smooth muscle actin expression upregulates fibroblast contractile activity," Molecular Biology of the Cell (MBoC), vol. 12, no. 9, pp. 2730-2741, 2001.

[9] K. K. Kharbanda, D. D. Rogers, T. A. Wyatt, M. F. Sorrell, and D. J. Tuma, "Transforming growth factor- $\beta$ induces contraction of activated hepatic stellate cells," Journal of Hepatology, vol. 41, no. 1, pp. 60-66, 2004.

[10] A. M. Gressner, R. Weiskirchen, K. Breitkopf, and S. Dooley, "Roles of TGF-beta in hepatic fibrosis," Frontiers in Bioscience, vol. 7, pp. d793-d807, 2002.

[11] S. Dooley and P. Ten Dijke, "TGF- $\beta$ in progression of liver disease," Cell and Tissue Research, vol. 347, no. 1, pp. 245-256, 2012.

[12] L. R. Gomes, L. F. Terra, R. A. M. Wailemann, L. Labriola, and M. C. Sogayar, "TGF- $\beta 1$ modulates the homeostasis between MMPs and MMP inhibitors through p38 MAPK and ERK1/2 in highly invasive breast cancer cells," BMC Cancer, vol. 12, article 26, 2012.

[13] D. C. LeBert, J. M. Squirrell, J. Rindy et al., "Matrix metalloproteinase 9 modulates collagen matrices and wound repair," Development, vol. 142, no. 12, pp. 2136-2146, 2015.

[14] H. Wang, F. Lafdil, L. Wang, S. Yin, D. Feng, and B. Gao, “Tissue inhibitor of metalloproteinase 1 (TIMP-1) deficiency exacerbates carbon tetrachloride-induced liver injury and fibrosis in mice: Involvement of hepatocyte STAT3 in TIMP-1 production," Cell \& Bioscience, vol. 1, no. 1, article 140, 2011.

[15] Y. Xie, R. Liao, L. Pan, K. Fan, C. Peng, and C. Du, "Hepatic stellate cell conditioned medium induces proliferation and epithelial-mesenchymal transition via activating ERK1/2 signaling pathway in hepatoma cells," Xi Bao Yu Fen Zi Mian Yi Xue Za Zhi, vol. 33, pp. 210-214, 2017.

[16] F. Y. Ma, M. Sachchithananthan, R. S. Flanc, and D. J. NikolicPaterson, "Mitogen activated protein kinases in renal fibrosis," Frontiers in Bioscience, vol. 1, no. 1, pp. 171-187, 2009. 
[17] H. L. Reeves, C. L. Dack, M. Peak, A. D. Burt, and C. P. Day, "Stress-activated protein kinases in the activation of rat hepatic stellate cells in culture," Journal of Hepatology, vol. 32, no. 3, pp. 465-472, 2000

[18] M. Junsi and S. Siripongvutikorn, "Thunbergia laurifolia, a traditional herbal tea of Thailand: Botanical, chemical composition, biological properties and processing influence," International Food Research Journal, vol. 23, no. 3, pp. 923-927, 2016.

[19] W. Boonyarikpunchai, S. Sukrong, and P. Towiwat, "Antinociceptive and anti-inflammatory effects of rosmarinic acid isolated from Thunbergia laurifolia Lindl.," Pharmacology Biochemistry \& Behavior, vol. 124, pp. 67-73, 2014.

[20] P. Pramyothin, H. Chirdchupunsare, A. Rungsipipat, and C. Chaichantipyuth, "Hepatoprotective activity of Thunbergia laurifolia Linn extract in rats treated with ethanol: In vitro and in vivo studies," Journal of Ethnopharmacology, vol. 102, no. 3, pp. 408-411, 2005.

[21] S. Aritajat, S. Wutteerapol, and K. Saenphet, "Anti-diabetic effect of Thunbergia laurifolia Linn. aqueous extract," The Southeast Asian Journal of Tropical Medicine and Public Health, vol. 35, pp. 53-58, 2004.

[22] E. Chan and Y. Lim, "Antioxidant activity of Thunbergia laurifolia tea," Journal of Tropical Forest Science, vol. 18, p. 130, 2006.

[23] A. Rocejanasaroj, T. Tencomnao, and W. Sangkitikomol, “Thunbergia laurifolia extract minimizes the adverse effects of toxicants by regulating P-glycoprotein activity, CYP450, and lipid metabolism gene expression in HepG2 cells," Genetics and Molecular Research, vol. 13, no. 1, pp. 205-219, 2014.

[24] A. Casini, M. Pinzani, S. Milani et al., "Regulation of extracellular matrix synthesis by transforming growth factor $\beta 1$ in human fat-storing cells," Gastroenterology, vol. 105, no. 1, pp. 245-253, 1993.

[25] E. R. Tamm, A. Siegner, A. Baur, and E. Lütjen-Drecoll, "Transforming growth factor- $\beta 1$ induces $\alpha$-smooth muscleactin expression in cultured human and monkey trabecular meshwork," Experimental Eye Research, vol. 62, no. 4, pp. 389397, 1996.

[26] L. Xu, A. Y. Hui, E. Albanis et al., "Human hepatic stellate cell lines, LX-1 and LX-2: new tools for analysis of hepatic fibrosis," Gut, vol. 54, no. 1, pp. 142-151, 2005.

[27] A. Desmouliere, A. Geinoz, F. Gabbiani, and G. Gabbiani, "Transforming growth factor- $\beta 1$ induces $\alpha$-smooth muscle actin expression in granulation tissue myofibroblasts and in quiescent and growing cultured fibroblasts," The Journal of Cell Biology, vol. 122, no. 1, pp. 103-111, 1993.

[28] A. Sebe, S.-K. Leivonen, A. Fintha et al., "Transforming growth factor- $\beta$-induced alpha-smooth muscle cell actin expression in renal proximal tubular cells is regulated by p $38 \beta$ mitogenactivated protein kinase, extracellular signal-regulated protein kinase1,2 and the Smad signalling during epithelialmyofibroblast transdifferentiation," Nephrology Dialysis Transplantation, vol. 23, no. 5, pp. 1537-1545, 2008.

[29] Y.-P. Han, C. Yan, L. Zhou, L. Qin, and H. Tsukamoto, "A matrix metalloproteinase- 9 activation cascade by hepatic stellate cells in trans-differentiation in the three-dimensional extracellular matrix," The Journal of Biological Chemistry, vol. 282, no. 17, pp. 12928-12939, 2007.

[30] F. Duval, J. E. Moreno-Cuevas, M. T. González-Garza, C. Maldonado-Bernal, and D. E. Cruz-Vega, "Liver fibrosis and mechanisms of the protective action of medicinal plants targeting inflammation and the immune response," International
Journal of Inflammation, vol. 2015, Article ID 943497, 14 pages, 2015.

[31] V. Hernandez-Gea and S. L. Friedman, "Pathogenesis of liver fibrosis," Annual Review of Pathology: Mechanisms of Disease, vol. 6, pp. 425-456, 2011.

[32] O. Skalli, P. Ropraz, A. Trzeciak, G. Benzonana, D. Gillessen, and G. Gabbiani, "A monoclonal antibody against alphasmooth muscle actin: a new probe for smooth muscle differentiation," The Journal of Cell Biology, vol. 103, no. 6, pp. 2787-2796, 1986.

[33] M. L. Hautekeete and A. Geerts, "The hepatic stellate (Ito) cell: Its role in human liver disease," Virchows Archiv, vol. 430, no. 3, pp. 195-207, 1997.

[34] T. Nouchi, Y. Tanaka, T. Tsukada, C. Sato, and F. Marumo, "Appearance of $\alpha$-smooth-muscle-actin-positive cells in hepatic fibrosis," Journal of Liver, vol. 11, no. 2, pp. 100-105, 1991.

[35] A. Schmitt-Gräff, S. Krüger, F. Bochard, G. Gabbiani, and H. Denk, "Modulation of alpha smooth muscle actin and desmin expression in perisinusoidal cells of normal and diseased human livers," The American Journal of Pathology, vol. 138, no. 5, pp. 1233-1242, 1991.

[36] R. C. Benyon, J. P. Iredale, S. Goddard, P. J. Winwood, and M. J. P. Arthur, "Expression of tissue inhibitor of metalloproteinases 1 and 2 is increased in fibrotic human liver," Gastroenterology, vol. 110, no. 3, pp. 821-831, 1996.

[37] J. P. Iredale, R. C. Benyon, M. J. P. Arthur et al., "Tissue inhibitor of metalloproteinase-1 messenger RNA expression is enhanced relative to interstitial collagenase messenger RNA in experimental liver injury and fibrosis," Hepatology, vol. 24, no. 1, pp. 176-184, 1996.

[38] H. I. Fallatah, "Noninvasive biomarkers of liver fibrosis: an overview," Advances in Hepatology, vol. 2014, Article ID 357287, 15 pages, 2014. 


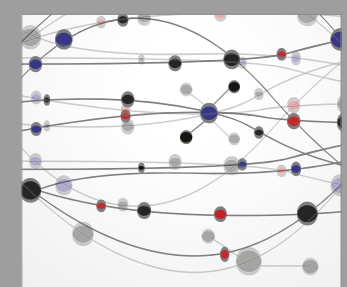

The Scientific World Journal
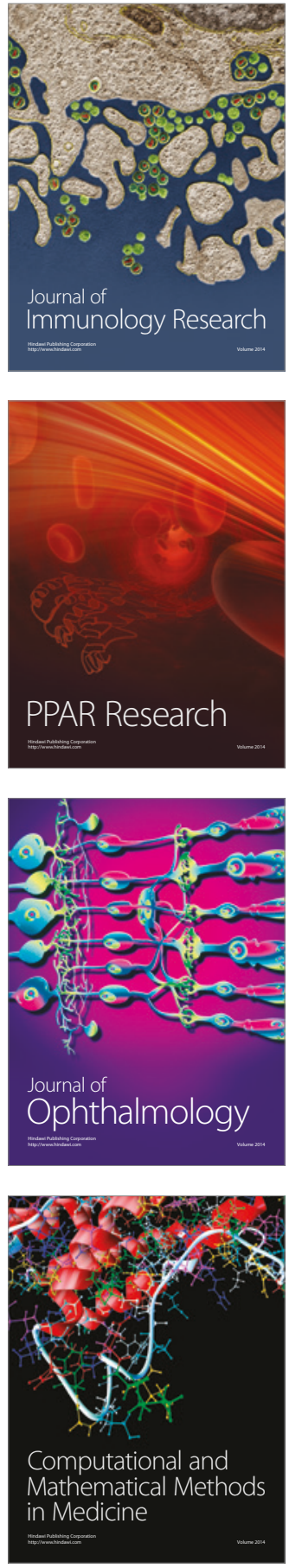

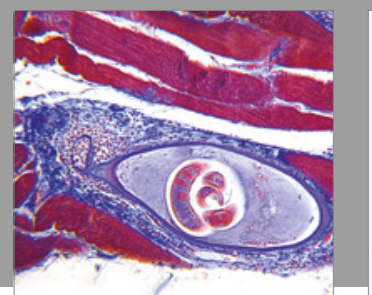

Gastroenterology Research and Practice
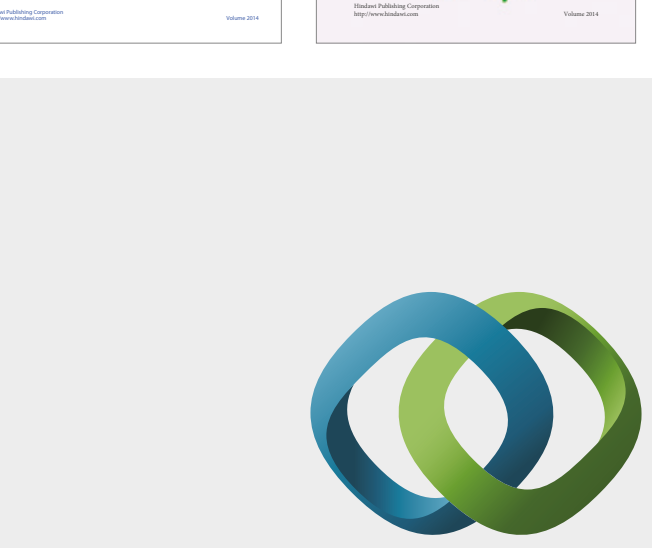

\section{Hindawi}

Submit your manuscripts at

https://www.hindawi.com
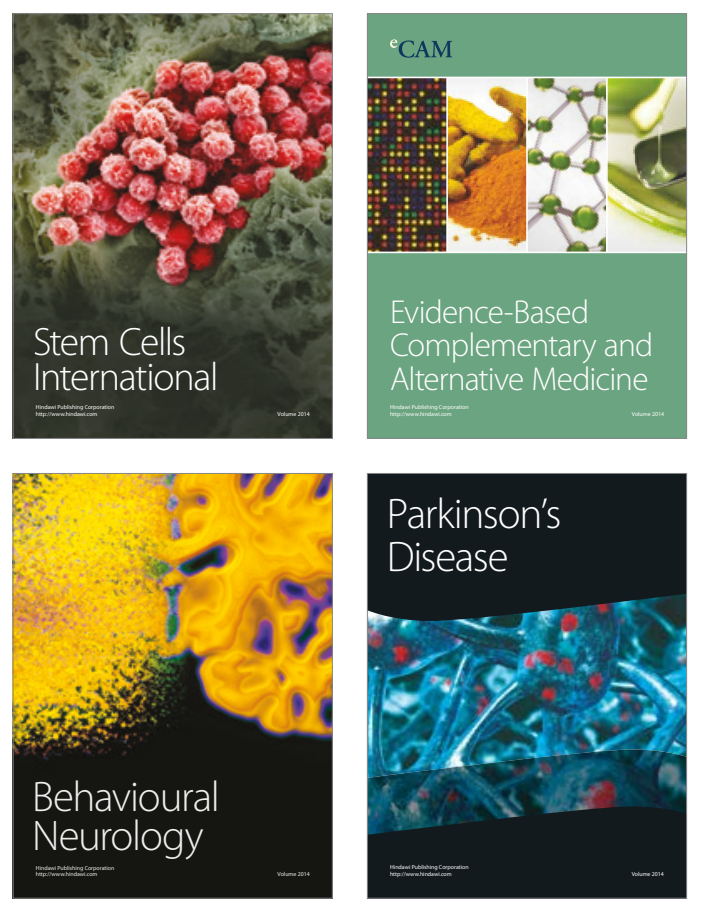
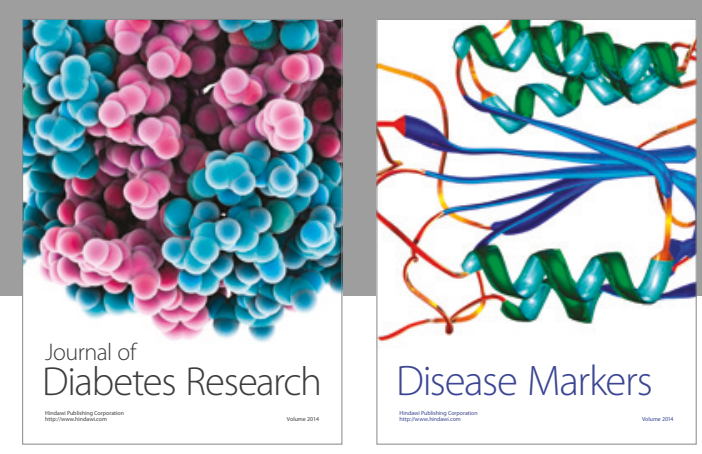

Disease Markers
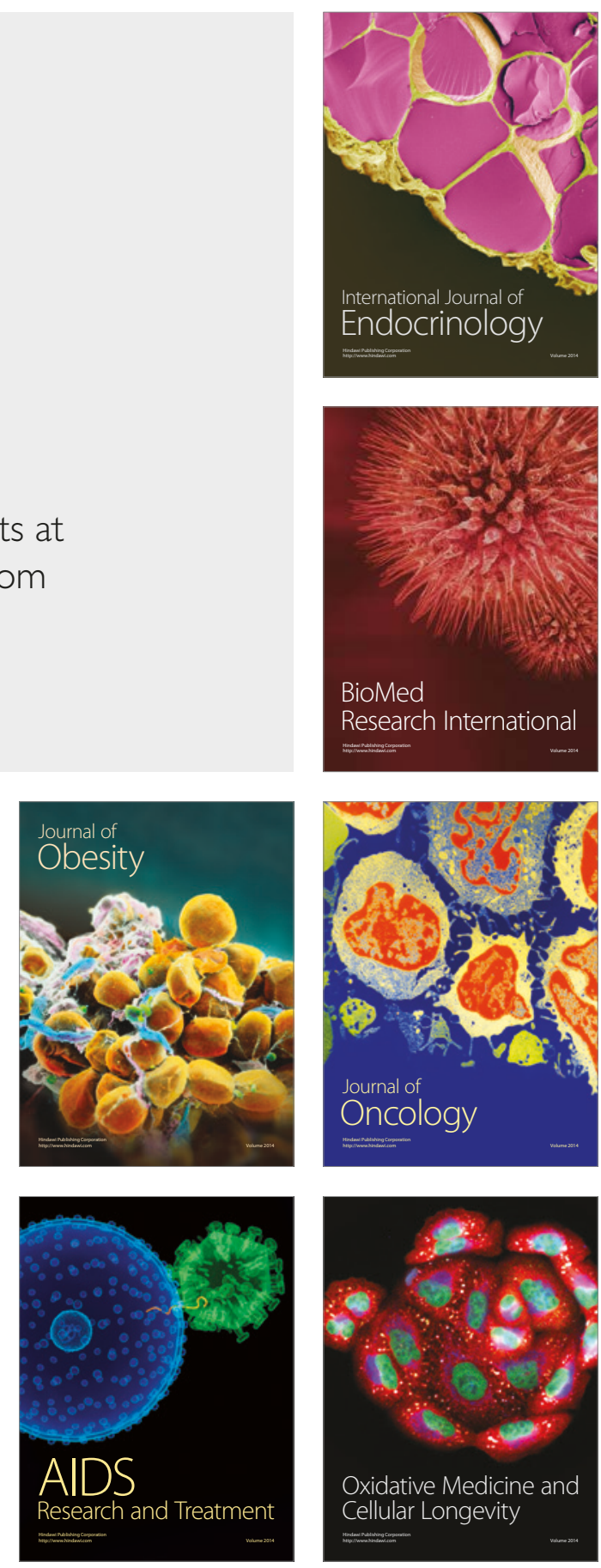